\title{
Polyacrylamide Gel Electrophoresis of Soluble Proteins from Several Genera of the Family Actinoplanaceae
}

\author{
F. L. DAVIES ${ }^{1}$ and D. GOTTLIEB \\ Department of Plant Pathology, University of Illinois, Urbana, Illinois 61801
}

\begin{abstract}
Soluble proteins were obtained from cells of various species of the family Actinoplanaceae and subjected to electrophoretic examination in polyacrylamide gels. The protein profiles so obtained showed a strong species specificity; they might be useful in species characterization. Little or no characteristic intrageneric pattern could be established for Actinoplanes, Streptosporangium, Microellobosporia, Ampullariella, or Spirillospora. The electrophoretic patterns are discussed in relation to the taxonomy of the family.
\end{abstract}

The electrophoretic resolution of soluble cell proteins in polyacrylamide gels has, in recent years, found fairly wide application as a taxonomic technique. The protein profiles of various organisms, including fungi (2), bacteria (12), and streptomycetes (9), have been examined. Most such studies, however, have been confined to comparisons at the level of strains or species, whereas in the present work an attempt was made to apply the method to a study and separation of genera. The protein profiles of species belonging to several genera of the family Actinoplanaceae were examined to see whether it was possible to discern any characteristic and reproducible patterns common to species of each genus.

At the same time, it was ho jed that this work might help to clarify existing taxonomic boundaries within the family. For instance, the generic separations proposed by Couch (3-6) have been questioned by Szanizlo and Gooder (15) as a result of a study of cell wall composition, and the inclusion of certain genera in the family Actinoplanaceae is somewhat uncertain at the present time. Protein profiles of species in such genera were investigated in an attempt to clarify their status.

\section{MATERIALS AND METHODS}

Organisms. The strain designations and sources of the actinomycete cultures used are given in Table 1 .

Culture methods. Preliminary experiments indicated that the medium which allowed a reasonable amount

${ }^{1}$ Present address: National Institute for Research in Dairying, University of Reading, Shinfield, Reading, U.K. of growth for the maximum number of cultures contained: yeast extract (Difco) (1\%), glucose (1\%), and tryptone (Difco) (1\%). This medium was used as a broth to grow mycelium for each experiment and as a solid (1.5\% agar) for the maintenance of stock slants. Mycelium from stock slants was suspended in $50 \mathrm{ml}$ of broth, blended for $30 \mathrm{~s}$ in a Waring blendor, and 5 or $10 \mathrm{ml}$ of the homogenate was then transferred to 100 $\mathrm{ml}$ of broth in a 500-ml Erlenmeyer flask. This culture was incubated at $25 \mathrm{C}$ on a reciprocal shaker $(95$ strokes per $\mathrm{min}$ ) for 3 to 4 days to provide an inoculum from which $5-\mathrm{ml}$ samples were used to seed $100-\mathrm{ml}$ batches of broth in $500-\mathrm{ml}$ Erlenmeyer flasks. These were incubated in the same manner as the inoculum, but for 5 days.

Extraction of soluble proteins. The mycelium was harvested by centrifugation at about $10,000 \times g$ and at $4 \mathrm{C}$, washed three times with cold, distilled water, and either stored at $-10 \mathrm{C}$ or used immediately. Approximately $5 \mathrm{~g}$ (fresh weight) of mycelium was mixed with a sufficient volume of cold, distilled water to form a heavy paste, which was then disrupted by passage through a French pressure cell at 20,000 $\mathrm{lb} / \mathrm{in}^{2}$ and $4 \mathrm{C}$. It was shown previously $(1,9)$ that water served as well as buffers for the extraction of soluble proteins from mycelium. The resulting slurry was centrifuged at $25,000 \times g$ for $20 \mathrm{~min}$ to remove cell debris. The supernatant fluid was further clarified by ultracentrifugation (Spinco model L) at 100,000 $X$ $g$ and $4 \mathrm{C}$ for $60 \mathrm{~min}$. This second centrifugation gave cleaner and more reproducible extracts while having no deleterious effect on the protein profiles subsequently obtained; similar results were found by Bent (1). The protein content of the final clear supernatant fluid was determined by the method of Lowry et al. (11), using bovine serum albumin as the standard.

Electrophoresis. Electrophoresis was performed essentially as described by Davis (7), using purified chemicals and a model 12 apparatus both from Canalco Corp., Bethesda, Md. Gel columns were formed in glass tubes $6 \mathrm{~cm}$ long with an internal 
TABLE 1. Strains studied

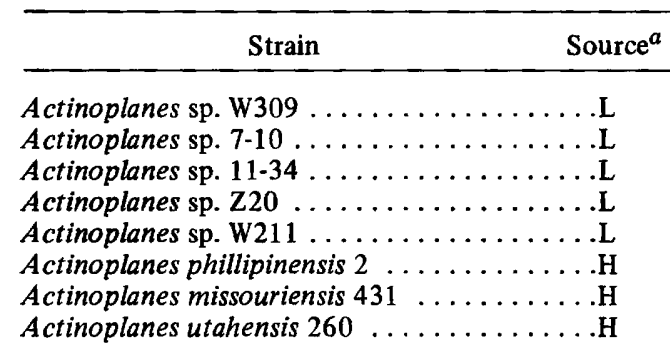

Ampullariella lobata $15350 \ldots \ldots \ldots \ldots$. . . . Ampullariella digitata $15349 / 1 \ldots \ldots \ldots \ldots$. . . Ampullariella digitata $33 \ldots \ldots \ldots \ldots \ldots \ldots$ Ampullariella campanulata $65 \ldots \ldots \ldots \ldots$ Ampullariella regularis $168 \ldots \ldots \ldots \ldots \ldots$

Amorphosporangium auranticolor $253 \ldots \ldots$. H

Streptosporangium roseum $\mathrm{J} 7 \ldots \ldots \ldots$ L Streptosporangium roseum $27 \ldots \ldots \ldots \ldots$. Streptosporangium sp. 9-26 ............ Streptosporangium sp. 9-14 ..........L Streptosporangium sp. E8 ..........W

Spirillospora albida $15331 \ldots \ldots \ldots \ldots$. . . . L Spirillospora albida $1030 \ldots \ldots \ldots \ldots \ldots \ldots$ Spirillospora sp. $14541 \ldots \ldots \ldots \ldots \ldots \ldots$ L

Microellobosporia cineria 3855 . . . . . . L Microellobosporia flavea 3857R L Microellobosporia violacea 795 .........L

Elytrosporangium brasiliense $2572 \ldots \ldots \ldots$ L

Planomonospora sp. 1800 ............

Streptomyces endus OWU587 .......... Streptomyces antibioticus NRRLB1793 ..... Streptomyces griseus $04833 \ldots \ldots \ldots \ldots$. . . . DD

Nocardia sp. $37-56 \ldots \ldots \ldots \ldots \ldots \ldots$. . . L

${ }^{a}$ L, H. A. Lechevalier, University of Rutgers; H, W. K. Hanton, University of North Carolina; W, S. T. Williams, University of Liverpool; PD, Park, Davis and Co., Detroit, Mich.

diameter of $1.5 \mathrm{~cm}$. Protein concentrations of extracts were adjusted with water so that $300 \mu \mathrm{g}$ of protein was applied to each gel column in $0.2-\mathrm{ml}$ sample gel. The separating gel contained $7 \%$ acrylamide and was designed to run at a $\mathrm{pH}$ of 9.5. A stacking gel was used between the sample and separating gels. Using an electrophoresis buffer with a pH of 8.3 at both the anode and cathode, a current of $4 \mathrm{~mA}$ per tube was applied for $40 \mathrm{~min}$ at room temperature. The sample front, as marked by bromophenol blue tracking dye, traveled approximately 1.25 inch (approximately 3.2 $\mathrm{cm}$ ) through the separating gel in this time. At this stage, tubes were laid in an ice bath for several minutes prior to removing the gels and staining them with amido black $(0.5 \%$ in $7 \%$ acetic acid) for $4 \mathrm{~h}$. Destaining was performed electrophoretically in $7 \%$ acetic acid at $12.5 \mathrm{~mA}$ per gel for about $45 \mathrm{~min}$ so that as much residual amido black as possible was removed, leaving dark or pale blue protein bands. Gels were scanned with a Canalco model F microdensitometer to record both the positions and intensity of staining of the bands. By the simultaneous use of a pulse integrator it was possible to assess the percentage of total protein applied to the gel which was present in each band. Since minor variations occurred in the actual distance the front traveled within different gels, band positions were calculated as the ratio of distance traveled by the protein to the distance traveled by the front $\left(E_{F}\right)$. These measurements were much more easily made from the densitometric tracing than from the actual gels.

\section{RESULTS AND DISCUSSION}

Reproducibility of the protein profiles from any one isolate was good, especially between replicate gels of the same experiment. Despite the application of apparently standard quantities $(300 \mu \mathrm{g})$ of protein, variations did occur in the overall staining intensities of gels run from different extracts. Possibly the presence of varying amounts of phenolic compounds in these extracts interfered with the determination of their protein content in the assay method used. To allow more extract comparison between gels, an effort was therefore made to quantitate band strengths by assessing their relative protein contents from the integrator pulses. Figure 1 shows how band strengths and positions were determined and represented diagrammatically. Figures 2 to 8 are derived in a similar manner.

Of the cultures examined, three species were each represented by two strains. From Fig. 2 it can be seen that there is a very strong similarity between the protein profiles of the different strains within each species. The affinity between the two strains of Spirillospora albida and between the two of Ampullariella digitata was particularly striking; only two or three minor bands, of a total of over twenty, were not common to each member of a pair. Although Streptosporangium roseum strain 27 exhibited four protein bands not apparent in the profile for Streptosporangium roseum J7, there were, nevertheless, 21 bands which compared very closely in position and intensity. Similar affinities have been found between strains of Mycoplasma species (14) and between strains of Streptomyces species (9). Besides indicating the closeness between strains, the three pairs of protein profiles presented here are testimony to the accuracy of the technique at this level. Also, despite having been maintained in different laboratories on different stock media, when the cultures were grown up and examined here, the profiles of their soluble 

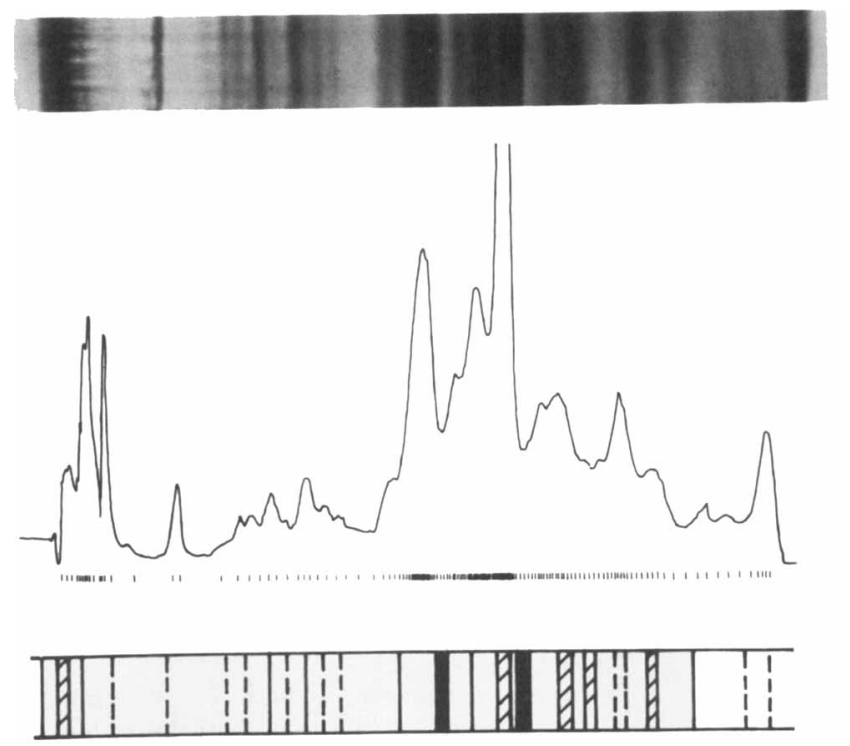

FIG. 1. An example of a stained gel (a) prepared as described in Materials and Methods, with its densitometer tracing (b) and integrator pulses (c). The diagrammatic representation (d) shows band positions based on $E_{F}$ determinations calculated from the densitometer tracing, and band strengths classified into four categories (

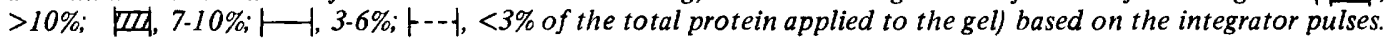
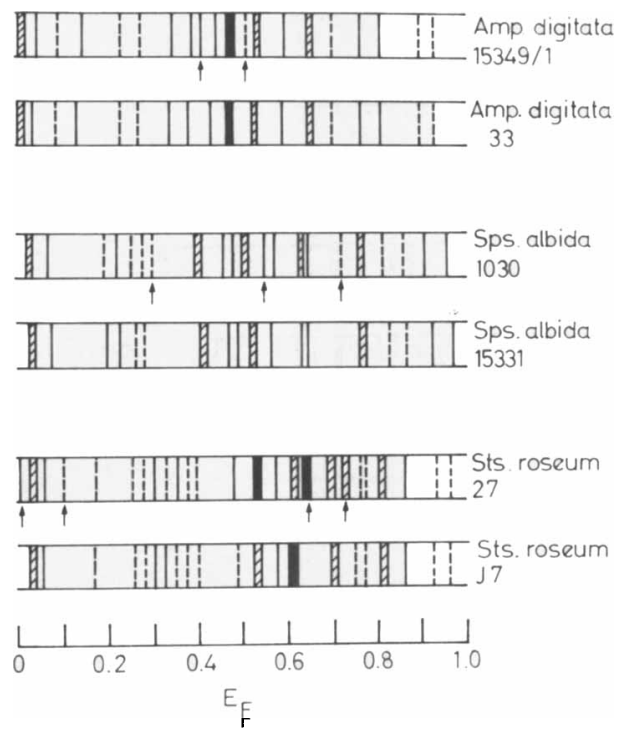

FIG. 2. Protein profiles of strains of Ampullariella (Amp.), Spirillospora (Sps.), and Streptosporangium (Sts.). Arrows indicate bands not common to both strains of a species. Methods and notations as for Fig. 1 .

proteins were very similar, which suggests that such profiles constitute a stable characteristic.

If, however, the profiles of different species of the various genera are compared (Fig. 3-8), it is evident that there is little affinity between the species within a genus. There appears to be no truly characteristic profile for most of the genera studied; only Streptosporangium had a few weak bands common to its species. Figure 3 shows the protein profiles of three species and five unnamed isolates of the genus Actinoplanes. It is evident that no intrageneric characteristic pattern was present; the number of bands varies from 14 to 22 , and the positions and intensities of these bands were highly variable; the profiles appeared to be species specific. The results also suggest that the

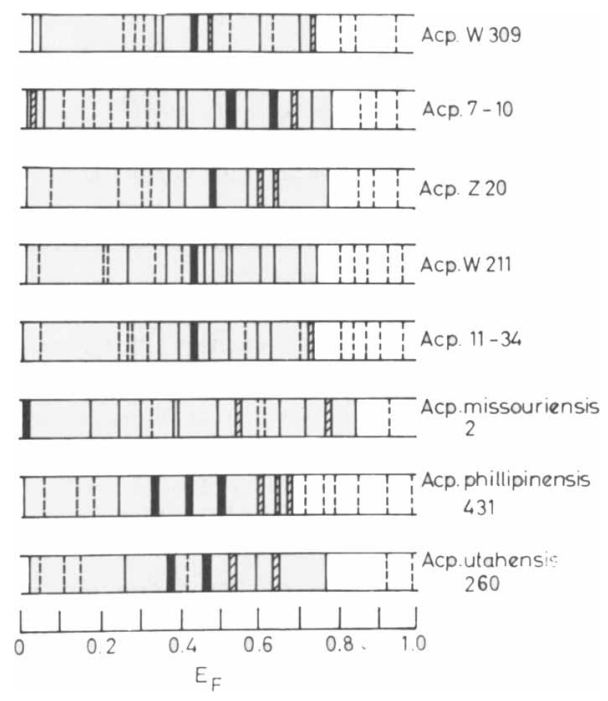

FIG. 3. Protein profiles of eight strains of Actinoplanes (Acp.). Methods and notations as for Fig. 1 . 

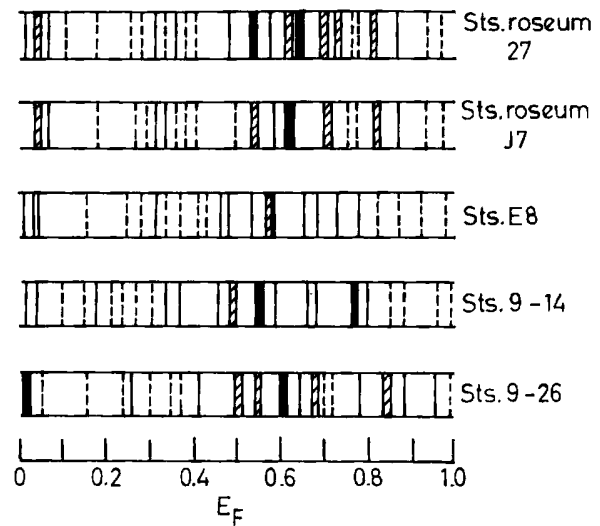

FIG. 4. Protein profiles of five strains of Streptosporangium (Sts.). Methods and notations as for Fig. 1 .
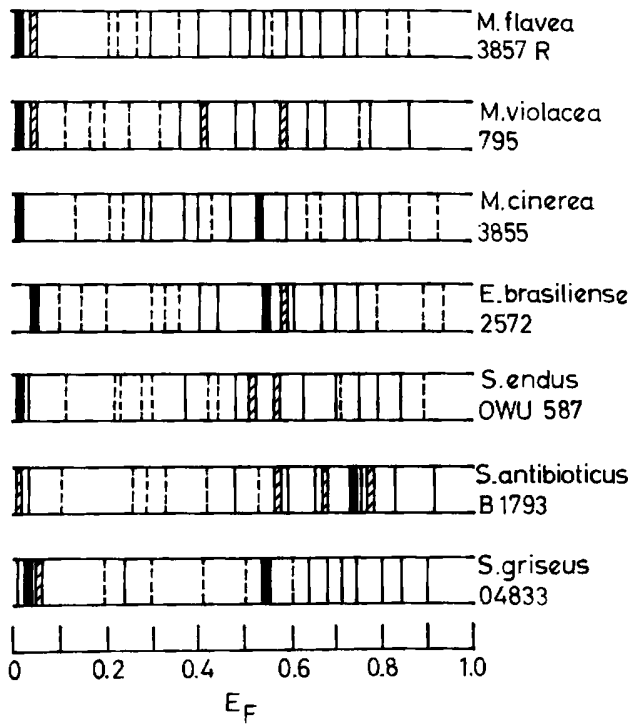

FIG. 5. Protein profiles of strains of Microellobosporia (M.), Elytrosporangium (E.) and Streptomyces (S.). Methods and notations as for Fig. 1.

unnamed strains are different both from each other and the named isolates.

Likewise, it is apparent from Fig. 4 that considerable divergence exists between the protein profiles of four species of Streptosporangium; the only common characteristic is a tendency for seven or eight slowly moving faint bands to occur in the region $E_{F} 0.1$ to $E_{F}$ 0.4 . Again each species exhibits its own specific pattern.

The protein profiles of three species of the genus Microellobosporia, one species of Elytrosporangium, and three of Streptomyces are compared in Fig. 5. It has been suggested by Prauser, Lisollette, and Falta (13) that the genus Microellobosporia is wrongly placed in the family Actinoplanaceae and should be transferred to the family Streptomycetaceae, to which it shows greater affinity on the basis of cell wall composition, serology, and other criteria. Unfortunately, the interspecific variations of the profiles obtained here obscure any affinities of this genus to either family. The representative of the genus Elytrosporangium was included here since, according to Falcao de Morais (8), it strongly resembles members of the genus Microellobosporia. Thiemann and Beretta (17), on the other hand, consider elytrosporangia to be indistinguishable from typical streptomycetes. The protein profile of the Elytrosporangium representative, however, is quite distinct from those of any of the Streptomyces or Microellobosporia strains studied.

Figures 6 and 7, showing the profiles of species of the genera Ampullariella and Spirillospora, indicate once again a strong degree of intrageneric heterogeneity in the electrophoretic mobilities of their proteins.

Single representatives of two more Actinoplanaceae genera, Amorphosporangium and

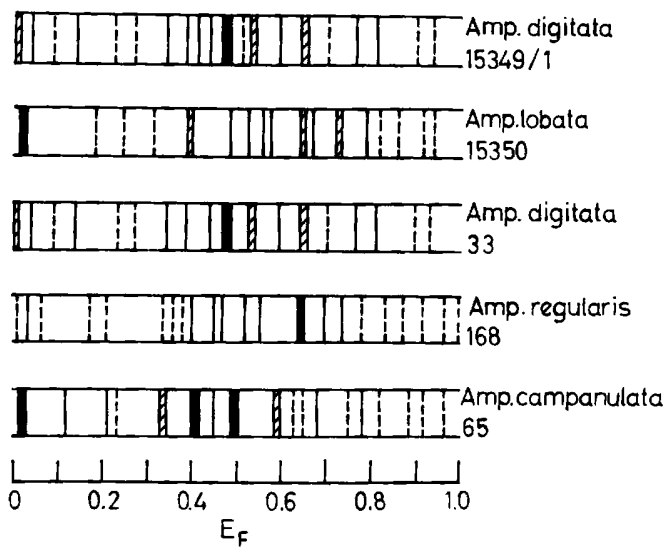

FIG. 6. Protein profiles of five strains of Ampullariella (A mp.). Methods and notations as for Fig. 1 .
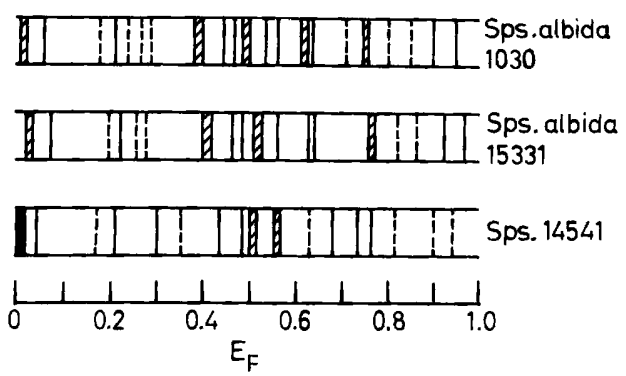

FIG. 7. Protein profiles of three strains of Spirillospora (Sps.). Methods and notations as for Fig. 1 . 

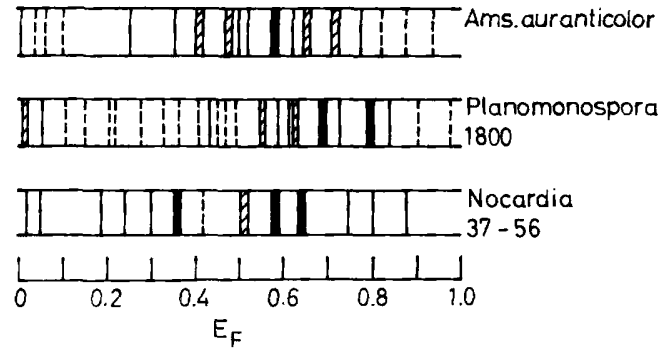

FIG. 8. Protein profiles of single strains of Amorphosporangium (Ams.), Planomonospora, and Nocardia. Methods and notations as for Fig. 1 .

Planomonospora, and one species of Nocardia are represented by their protein profiles in Fig. 8. Amorphosporangium was separated by Couch (5) from Actinoplanes on the basis of the nonmotility of the spores and the shape of the sporangia of members of the former genus. More recently, Hanton (10) demonstrated the presence of flagellated sporangiospores in Amorphosporangium auranticolor. One might expect, therefore, that the protein profile of this organism (Fig. 8) would be similar to one or more of those of the Actinoplanes species (Fig. 3). It can be seen, however, that it bears no greater affinity to these than to species of the other genera studied.

The Nocardia culture (madurae type) was included because it forms conidial chains reminiscent of sporangia (Lechevalier, personal communication). In its electrophoretic pattern, however, it is unlike any of the cultures of the family Actinoplanaceae examined in that it exhibits only 13 bands.

Planomonospora was described by Thiemann et al. (18) as being distinctly different from any of the other members of Actinoplanaceae. The strain of Planomonospora examined here (Fig. 8) also shows no obvious resemblance to any of the other genera studied.

In an electrophoretic study of membrane protein from bacterial L-forms, Theodore, King, and Cole (16) were able to demonstrate intrageneric similarities between species of Proteus and between species of Staphylococcus indicating a close affinity between the species within each genus. No such intrageneric characteristics could be demonstrated for the soluble protein profiles obtained from the genera used in the current study; the patterns can be said to be species or strain specific. Szaniszlo and Gooder (15), from chromatographic examination of the amino acids in cell walls of the genera Actinoplanes, Ampullariella, Amorphosporangium, and Pilimelia, concluded that these amino acids were species specific but not genus specific. A similar conclusion was reached here for the soluble proteins of these organisms. Szaniszlo and Gooder (15) went on to propose a single genus concept for the family Actinoplanaceae on the grounds that insufficient evidence existed for the separation of different genera. Neither do the protein profiles obtained in the present study suggest any obvious generic groupings for species belonging to this family.

Our results probably reflect the inadequacy of the electrophoretic technique for taxonomy at the generic level, rather than indicating the natural relationships of the members of the family Actinoplanaceae studied. For instance the Streptomyces protein profiles in Fig. 5 show little similarity to one another, whereas many morphological and biochemical characteristics illustrate their close relationship. In summary, we consider that gel electrophoresis of soluble cell proteins provides a useful technique for the separation of strains and species but that the interspecific variation of protein profiles is so large as to preclude its extension to separation of genera, at least within the family studied here.

\section{ACKNOWLEDGMENTS}

One of us (F.L.D.) wishes to acknowledge a Wellcome Trust Travel Grant.

\section{LITERATURE CITED}

1. Bent, K. J. 1967. Electrophoresis of proteins of three Penicillium species on acrylamide gels. J. Gen. Microbiol. 49:195-200.

2. Chang, L. O. Srb. A. M., and F. C. Steward. 1962. Electrophoretic separation of the soluble proteins of Neurospora. Nature (London) 193:756-759.

3. Couch, J. N. 1950. Actinoplanes, a new genus of the Actinomycetales. J. Elisha Mitchell Sci. Soc. 66: 87-92.

4. Couch, J. N. 1955. A new genus and family of the Actinomycetales, with a revision of the genus Actinoplanes. J. Elisha Mitchell Sci. Soc. 71:148-155.

5. Couch, J. N. 1963. Some new genera and species of the Actinoplanaceae. J. Elisha Mitchell Sci. Soc. 79: 53-70.

6. Couch, J. N. 1964. A proposal to replace the name Ampullaria with Ampullariella. J. Elisha Mitchell Sci. Soc. 80: 29.

7. Davis, B. J. 1964. Disc electrophoresis. 11. Method and application to human serum proteins. Ann. N.Y. Acad. Sci. 121:404-427.

8. Falcao de Morais. 1967. The genus Elytrosporangium and its relationship to Micro. ellobosporia and Streptomyces. Hindustan Antibiot. Bull. 9:135-137.

9. Gottlieb, D., and P. M. Hepden. 1966. The electrophoretic movement of proteins from various Streptomyces species as a taxonomic criterion. J. Gen. Microbiol. 44:95-104. 
10. Hanton, W. K. 1968. Amorphosphorangium (Actinoplanaceae): report of motility and additional characters. J. Gen. Microbiol. 53:31 7-320.

11. Lowry, O. H., N. J. Rosebrough, N. L. Farr, and R. J. Randall. 1951. Protein measurement with the Folin phenol reagent. J. Biol. Chem. 193: $265-275$.

12. Lund, B. M. 1965 . A comparison by the use of gel electrophoresis of soluble protein components and esterase enzymes of some group D streptococci. J. Gen. Microbiol. 40:413-419.

13. Prauser, H., M. Lisolette, and R. Falta. 1967. On the taxonomic position of the genus Microellobosporia Cross, Lecavalier and Lechevalier 1963. Int. J. Syst. Bacteriol. 17:361-366.
14. Rottem, S., and S. Razine. 1967. Electrophoretic patterns of membrane proteins of Mycoplasma. J. Bacteriol. 94: 359-364.

15. Szaniszlo, P. J., and H. Gooder. 1967. Cell wall composition in relation to the taxonomy of some Actinoplanaceae. J. Bacteriol. 94: 2037-2047.

16. Theodore, T. S., J. R. King, and R. M. Cole. 1969. Identification of $\mathrm{L}$-forms by polyacrylamide-gel electrophoresis. J. Bacteriol. 97:495-499.

17. Thiemann, J. E., and G. Beretta. 1968. A new genus of the Actinoplanaceae: Planobispora gen. nov. Archiv. für Mikrobiol. 62:157-166.

18. Thiemann, J. E., H. Pagani, and G. Beretta. 1967. A new genus of the Actinoplanaceae: Planomonospora gen. nov. Giorn. Mikrobiol. 15:27-38. 